einstein

Official Publication of the Instituto Israelita

de Ensino e Pesquisa Albert Einstein

ISSN: 1679-4508 | e-ISSN: 2317-6385
How to cite this article:

Sarno F, Bittencourt CA, Oliveira SA. Profile of patients with hypertension and/or diabetes mellitus from Primary Healthcare units. einstein (São Paulo). 2020;18:eA04483. http://dx.doi.org/ 10.31744/einstein journal/2020A04483

Corresponding author:

Flavio Sarno

Rua Lira Cearense, 458 - Jardim Santa Efigênia Zip code: 05763-450 - São Paulo, SP, Brazil

Phone: (55 11) 99320-6194

E-mail: flaviosarno@gmail.com

Received on:

Mar 23, 2018

Accepted on:

Nov 12, 2018

Conflict of interest:

none.

Copyright 2020

(c) BY

This content is licensed

under a Creative Commons

Attribution 4.0 International License.
ORIGINAL ARTICLE

\section{Profile of patients with hypertension} and/or diabetes mellitus from Primary Healthcare units

\author{
Perfil de pacientes com hipertensão arterial e/ou \\ diabetes mellitus de unidades de Atenção Primária à Saúde \\ Flavio Sarno', Clarissa Alves Gomes Bittencourt', Simone Augusta de Oliveira' \\ 1 Instituto Israelita de Responsabilidade Social, Hospital Israelita Albert Einstein, São Paulo, SP, Brazil.
}

Doi: 10.31744/einstein_journal/2020A04483

\section{ABSTRACT}

Objective: To analyze the characteristics of patients with hypertension and/or diabetes mellitus from Primary Healthcare units. Methods: This is a retrospective study, with data collected from December 2014 of patients with hypertension and/or diabetes from 13 Primary Healthcare units located in the Southern region of Sao Paulo (SP, Brazil). Patients were compared by sex, diagnosis and cardiovascular risk using student $t$ test, one way analysis of variance (ANOVA), and MannWhitney, Kruskal-Wallis and $\chi^{2}$ tests. Results: We evaluated 28,496 patients aged 20 years to 79 years (mean of 57.8 years). Most of patients were women (63.2\%) and aged 50 years old or older (74.2\%). The participation in the Programa Remédio em Casa (Medicine at Home Program) was higher among women (12.7\%), and the proportions of hypertension, diabetes and both diseases were $68.0 \%, 7.9 \%$ and $24.1 \%$, respectively. Patients with hypertension and diabetes had higher participation in Medicine at Home Program (13.3\%), and those with diabetes only had higher participation in Programa de Automonitoramento Glicêmico (Self-Monitoring Glucose Program) (20.0\%). The proportions of low, moderate, and high cardiovascular risk were $33.0 \%, 15.5 \%$, and $51.5 \%$, respectively. Conclusion: The sample of this study consisted of patients who were mostly women, aged 50 years or older and diagnosed with hypertension. Almost a quarter of patients also had diabetes and approximately one third and half of them were classified as low and high cardiovascular risk.

Keywords: Chronic disease; Hypertension; Diabetes mellitus; Primary Health Care; Population characteristics

\section{RESUMO}

Objetivo: Analisar as características de pacientes com hipertensão arterial e/ou diabetes mellitus de unidades de Atenção Primária à Saúde. Métodos: Estudo retrospectivo, com dados de dezembro de 2014 de pacientes com hipertensão e/ou diabetes, de 13 unidades de Atenção Primária à Saúde localizadas na região sul da cidade de São Paulo (SP). Os pacientes foram comparados por sexo, diagnósticos e risco cardiovascular, por meio dos testes $t$ de Student, análise de variância de um fator, Mann-Whitney, Kruskal-Wallis e $\chi^{2}$. Resultados: Foram avaliados 28.496 pacientes, de 20 anos a 79 anos de idade (média de 57,8 anos), sendo a maioria do sexo feminino $(63,2 \%$ ) e com 50 anos ou mais de idade (74,2\%). A participação no Programa Remédio em Casa foi maior no sexo feminino $(12,7 \%)$ e as proporções de hipertensão, diabetes e de ambas as doenças foram de $68,0 \%, 7,9 \%$ e $24,1 \%$, respectivamente. 0 s pacientes com hipertensão e diabetes apresentaram maior proporção de participação no Programa Remédio em Casa $(13,3 \%)$ e aqueles com apenas diabetes apresentaram maior proporção de participação no Programa de Automonitoramento Glicêmico (20,0\%). As proporções de risco cardiovascular baixo, moderado e alto foram de $33,0 \%, 15,5 \%$ e $51,5 \%$, respectivamente. Conclusão: A amostra deste estudo foi constituída 
por pacientes em sua maioria do sexo feminino, com 50 anos ou mais de idade e diagnóstico de hipertensão. Cerca de um quarto dos pacientes apresentava também diabetes e aproximadamente um terço e metade deles foram categorizados como risco cardiovascular baixo e alto, respectivamente.

Descritores: Doença crônica; Hipertensão; Diabetes mellitus; Atenção Primária à Saúde; Características da população

\section{INTRODUCTION}

Arterial hypertension and diabetes mellitus are the two most prevalent chronic diseases worldwide. In population-based studies including individuals aged older than 18 years, global hypertension prevalence in 2015 was estimated in $24.1 \%$ for men and $20.1 \%$ for women, which represents around 1.13 billion people. ${ }^{(1)}$ Regarding diabetes, systematic review of the literature estimated these values in $8.8 \%$, which would correspond to 415 million people aged between 20 and 79 years. ${ }^{(2)}$

In Brazil, hypertension and diabetes prevalence had similar values. In a study conducted in all Brazilian states capitals and Brazil capital in 2016, prevalence of hypertension in population aged older than 18 years was estimated in $25.7 \%$ and $8.9 \%$ in those with diabetes. $^{(3)}$

Besides being prevalent, these diseases are often associated with each other. A systematic literature review reported that in most studies including patients older than 18-year-old and who had diabetes, $50 \%$ or more also had hypertension. ${ }^{(4)}$ Similarly, among patients with hypertension who were registered in followingup and recording system of arterial hypertension and diabetes mellitus of the Brazilian Public Health System, around $22 \%$ to $25 \%$ of them also had diabetes. ${ }^{(5)}$

In public health policy, Primary Health Care (PHC) is considered the main entrance and communication center with users in healthcare network. ${ }^{(6)}$ With regard to chronic diseases, the PHC is responsible, among other actions, for screening, diagnosis and treatment, and should also prevent, diagnosis, and treat possible complications early and coordinate the integral and continuous care of these patients. ${ }^{(7)}$

Thus, the PHC has central role in the care of patients with hypertension and diabetes. In national health survey from 2013, almost half of patients with these disease reported having their last consultation in basic health units. ${ }^{(8,9)}$ And between 2014 and 2015, hypertension $(38.6 \%)$ and diabetes $(13.6 \%)$ appeared as two most common mentioned chronic diseases by patients aged older than 18 years from PHC services in Brazil. ${ }^{(10)}$
To meet the demands and needs of these patients, knowing their characteristics is an important part of organization of working processes and care for hypertension and diabetes in PHC services. ${ }^{(11)}$

\section{OBJECTIVE}

To analyse the characteristics of patients with hypertension and/or diabetes mellitus from Primary Healthcare units.

\section{METHODS}

This is a retrospective study, with data from patients with confirmed diagnosis of hypertension and/or diabetes from 13 PHC units, located in Southern region of Sao Paulo (SP, Brazil). These PHC units are administrated by Sociedade Beneficente Israelita Brasileira Hospital Albert Einstein, through a partnership with the Secretary of Health of the Municipality of Sao Paulo. These patients are assisted through the Family Health Strategy, used by Brazilian Ministry of Health as model for PHC expansion and consolidation in the country. ${ }^{(6)}$

Data were obtained directly from completed spreadsheets that were used by professionals of PHC units to assist patients with hypertension and/or diabetes. The following items, comprising December 2014, were analyzed: sex, age, hypertension and/or diabetes diagnosis, cardiovascular risk (CVR), calculated according to the Framingham's risk score, and participation of health programs (Medicine at Home Program - Medicine at Home Program and Self-Monitoring Glucose Program - SMGP). Medicine at Home Program is a home delivery of prescribed medicines to patients with stable and controlled chronic diseases, such as hypertension, diabetes, dyslipidemia, and hypothyroidism. ${ }^{(12)}$ The goal of SMGP is to provide, for insulin-dependent diabetes patients, the supplies required for self-monitoring of capillary blood glucose. ${ }^{(13)}$ Qualitative variables were described by absolute and relative frequencies, whereas age, in numerical format by mean and standard deviation. Patients were compared by sex, disease diagnosis, and CVR categories. Patients aged 20 to 79 years were inclued, once the Framingham score allows classifying CVR only in this age group. For statistical analysis, R 3.1.3 program was used, considering the significance level of 5\%. Student $t$ test for independent data, variance analysis (ANOVA) of one factor and Mann-Whitney, Kruskal-Wallis and the $\chi^{2}$ were used as needed. 
This study was approved by Ethical and Research Committee of the Hospital Israelita Albert Einstein (CAAE: 46573115.6.0000.0071) and by the Secretary of Health of the Municipality of Sao Paulo (CAAE: 46573115.6.3001.0086).

\section{RESULTS}

In December 2014, data from 28,496 patients aged between 20 and 79 years and confirmed diagnosis of hypertension and/or diabetes were analyzed. Patients' mean age was 57.8 years, mostly women $(63.2 \%)$, aged older than 50 years $(74.2 \%)$, with high CVR $(51.5 \%)$, and diagnosed with hypertension (68.0\%). Participations in MHP and SMGP were $11.4 \%$ and $6.1 \%$, respectively, and the former was significantly higher among women $(12.7 \%)$.

We also observed statistically significant differences in the distribution of proportions between sexes and classification of CVR and diseases diagnosis (Table 1).

Table 1. Distribution of patients, based on sex and study variables

\begin{tabular}{|c|c|c|c|c|}
\hline \multirow{2}{*}{ Variables } & \multicolumn{2}{|c|}{ Sex } & \multirow{2}{*}{ Total } & \multirow{2}{*}{ p value } \\
\hline & Women & Men & & \\
\hline Age, years & $57.8 \pm 12.0$ & $57.8 \pm 11.8$ & $57.8 \pm 11.9$ & $0.786^{*}$ \\
\hline Age range, years & & & & $0.797^{\dagger}$ \\
\hline $20-29$ & $268(1.5)$ & $153(1.5)$ & $421(1.5)$ & \\
\hline $30-39$ & $1187(6.6)$ & $658(6.3)$ & $1.845(6.5)$ & \\
\hline $40-49$ & $3,200(17.8)$ & $1,893(18.1)$ & $5,093(17.9)$ & \\
\hline $50-59$ & $5,213(28.9)$ & $2,966(28.3)$ & $8,179(28.7)$ & \\
\hline $60-69$ & $5,079(28.2)$ & $3,099(29.6)$ & $8,178(28.7)$ & \\
\hline $70-79$ & $3,068(17.0)$ & $1,712(16.3)$ & $4,780(16.8)$ & \\
\hline MHP & & & & $<0.001^{\ddagger}$ \\
\hline No & $15,729(87.3)$ & $9,495(90.6)$ & $25,224(88.6)$ & \\
\hline Yes & $2,281(12.7)$ & $980(9.4)$ & $3,261(11.4)$ & \\
\hline SMGP & & & & $0.510^{\ddagger}$ \\
\hline No & $16,866(94.0)$ & $9,789(93.8)$ & $26,655(93.9)$ & \\
\hline Yes & $1,083(6.0)$ & $651(6.2)$ & $1,734(6.1)$ & \\
\hline CVR & & & & $<0.001^{\ddagger}$ \\
\hline Low & $5,786(38.3)$ & $2,064(23.8)$ & $7,850(33.0)$ & \\
\hline Moderate & $2,098(13.9)$ & $1,584(18.3)$ & $3,682(15.5)$ & \\
\hline High & $7,229(47.8)$ & $5,030(58.0)$ & $12,259(51.5)$ & \\
\hline Diagnosis & & & & $<0.001^{\ddagger}$ \\
\hline Diabetes & $1,231(6.8)$ & $1,014(9.7)$ & $2,245(7.9)$ & \\
\hline Hypertension & $12,418(69.1)$ & $6,894(66.0)$ & $19,312(68.0)$ & \\
\hline Diabetes and Hypertension & $4,323(24.1)$ & $2,533(24.3)$ & $6,856(24.1)$ & \\
\hline Total & $18,015(63.2)$ & $10,481(36.8)$ & $28,496(100)$ & \\
\hline
\end{tabular}

Results in means \pm standard deviation or $n(\%) .{ }^{*}$ Student $t$ test; ${ }^{\dagger}$ Mann-Whitney test; ${ }^{\ddagger} \chi^{2}$ test. MHP: medicine at home program; SMGP: self-monitoring glucose program; CVR: cardiovascular risk.
The proportions of patients with diagnosis of hypertension, diabetes, and both diseases $(n=28,413)$ were $68.0 \%, 7.9 \%$ and $24.1 \%$, respectively. Patients with hypertension and diabetes had a higher mean age (61.5 years) and participation in MHP $(13.3 \%)$. We observed statistically significant differences in distributions of proportions between diagnosis and age and age range. Patients diagnosed with diabetes only had higher proportion of participation in SMGP (20.0\%), and around one fifth of patients with hypertension $(21.5 \%)$ were classified as high CVR (based on Framingham score, diabetes patients were classified with high CVR) (Table 2).

Table 2. Distribution of patients, based on diagnosis and study variables

\begin{tabular}{|c|c|c|c|c|}
\hline \multirow[b]{2}{*}{ Variables } & \multicolumn{3}{|c|}{ Diagnoses } & \multirow[b]{2}{*}{ p value } \\
\hline & Diabetes & Hypertension & $\begin{array}{l}\text { Diabetes and } \\
\text { hypertension }\end{array}$ & \\
\hline Age, years & $53.3 \pm 12.6$ & $57.0 \pm 11.9$ & $61.5 \pm 10.6$ & $<0.001^{*}$ \\
\hline Age range, years & & & & $<0.001^{\dagger}$ \\
\hline $20-29$ & $94(4.2)$ & $301(1.6)$ & $26(0.4)$ & \\
\hline $30-39$ & $248(11.0)$ & $1,380(7.1)$ & $213(3.1)$ & \\
\hline $40-49$ & $535(23.8)$ & $3,771(19.5)$ & $764(11.1)$ & \\
\hline $50-59$ & $656(29.2)$ & $5,715(29.6)$ & $1,782(26.0)$ & \\
\hline $60-69$ & $480(21.4)$ & $5,214(27.0)$ & $2,462(35.9)$ & \\
\hline $70-79$ & $232(10.3)$ & $2,931(15.2)$ & $1,609(23.5)$ & \\
\hline MHP & & & & $<0.001^{\ddagger}$ \\
\hline No & $2150(95.8)$ & 17,050 (88.3) & $5,942(86.7)$ & \\
\hline Yes & $94(4.2)$ & $2,254(11.7)$ & $913(13.3)$ & \\
\hline SMGP & & & & $<0.001^{\ddagger}$ \\
\hline No & $1,796(80.0)$ & $19,209(100.0)$ & $5,568(81.2)$ & \\
\hline Yes & $448(20.0)$ & $0(0.0)$ & 1,286 (18.8) & \\
\hline CVR & & & & - \\
\hline Low & $0(0.0)$ & $7,842(53.4)$ & $0(0.0)$ & \\
\hline Moderate & $0(0.0)$ & $3,680(25.1)$ & $0(0.0)$ & \\
\hline High & $2,245(100.0)$ & $3,154(21.5)$ & $6,856(100.0)$ & \\
\hline Total & $2,245(7.9)$ & $19,312(68.0)$ & $6,856(24.1)$ & \\
\hline
\end{tabular}

Results in means \pm standard deviation or $\mathrm{n}(\%) .{ }^{*}$ ANOVA variance analysis; ${ }^{*}$ Kruskal-Wallis test; ${ }^{\ddagger} \chi^{2}$ test. MHP: medicine at home program; SMGP: self-monitoring glucose program; CVR: cardiovascular risk.

In patients with calculated CVR $(n=23,791)$, proportions of low, moderate, and high risk were $33.0 \%$, $15.5 \%$ and $51.5 \%$, respectively. Patients with moderate CVR had higher mean age (60.5 years). We observed statistically significant differences in the proportions distributions between CVR categories and age, age range and participation in MHP (Table 3 ). 
Table 3. Distribution of patients, based on cardiovascular risk and study variables

\begin{tabular}{lcccc}
\hline \multirow{2}{*}{ Variables } & \multicolumn{3}{c}{ Cardiovascular risk } & \multirow{2}{*}{ p value } \\
\cline { 2 - 4 } & Low & Moderate & High & \\
\hline Age, years & $54.1 \pm 11.5$ & $60.5 \pm 10.5$ & $60.2 \pm 11.8$ & $<0.001^{*}$ \\
Age range, years & & & & $<0.001^{\dagger}$ \\
$20-29$ & $154(2.0)$ & $20(0.5)$ & $158(1.3)$ & \\
$30-39$ & $794(10.1)$ & $104(2.8)$ & $574(4.7)$ & \\
$40-49$ & $1,930(24.6)$ & $472(12.8)$ & $1,627(13.3)$ & \\
$50-59$ & $2,456(31.3)$ & $1,076(29.2)$ & $3,201(26.1)$ & \\
$60-69$ & $1,820(23.2)$ & $1,278(34.7)$ & $3,911(31.9)$ & \\
$70-79$ & $696(8.9)$ & $732(19.9)$ & $2,788(22.7)$ & \\
MHP & & & & $<0.001^{\ddagger}$ \\
No & $6,714(85.5)$ & $3,144(85.4)$ & $10,905(89.0)$ & \\
Yes & $1,136(14.5)$ & $538(14.6)$ & $1,352(11.0)$ & \\
SMGP & & & & - \\
No & $7,848(100.0)$ & $3,682(100.0)$ & $10,522(85.9)$ & \\
Yes & $0(0.0)$ & $0(0.0)$ & $1,734(14.1)$ & \\
Total & $7,850(33.0)$ & $3,682(15.5)$ & $12,259(51.5)$ & \\
\hline
\end{tabular}

Results in means \pm standard deviation or $\mathrm{n}(\%){ }^{*}$ ANOVA variance analysis; ${ }^{\dagger}$ Kruskal-Wallis test: ${ }^{\ddagger} \chi^{2}$ test. MHP: medicine at home program; SMGP: self-monitoring glucose program.

\section{DISCUSSION}

This study presented the characteristics of patients with hypertension and/or diabetes from 13 PHC units. The sample profile consisted of patients with 57.8 of mean age, most of them women, diagnosed with hypertension and classified with high CVR.

To compare the results obtained with those published in the literature, we chose to evaluate studies carried out in PHC units in south and southeast regions of Brazil with patients who had hypertension and/or diabetes. However, consideration should be given to differences in dates, locations and evaluated samples, which could have influenced patients characteristics.

Regarding the study conducted with patients with hypertensions and/or diabetes from the PHC of city of Porto Alegre (RS) in 2011, the mean age (64 years), and the proportion of women $(68.3 \%)$ were higher in comparison with our results (57.8 years and $63.2 \%$, respectively). The mean age of patients with hypertension (64 versus 57.0 years), diabetes (59 years versus 53.3 years) and those with both diseases (65.5 versus 61.5 years) and the proportion of women with hypertension (69.7\% versus $64.3 \%$ ), diabetes $(58.1 \%$ versus $54.8 \%$ ), and with both diagnoses (67.3\% versus $63.1 \%$ ) were also higher. ${ }^{(14)}$ It should be considered, however, that in the study from 2011 all patients were evaluated, and in our study those aged up to 79 years.

In comparing our findings with a study including patients with hypertension and/or diabetes who were assisted by the family health care teams in the city of Cambé (PR) in 2011 and 2012, the proportion of women was lower $(58.3 \%$ versus $63.2 \%)$ and the proportion of patients with 60 years or more was similar $(45.6 \%$ versus $45.5 \%) .{ }^{(15)}$ It should be taken into consideration that this study evaluated patients aged 40 years or older while our study those aged 20 to 79 years old.

In a study from 2008 conducted with patients with hypertension and/or diabetes from 3 PHC units of the city of Pelotras (RS), our results showed higher proportions of women with diabetes $(54.8 \%$ versus $46.7 \%)$ and fewer with hypertension $(64.3 \%$ versus $69.6 \%)$ and with both diseases $(63.1 \%$ versus $73.0 \%)$. The proportions of patients aged 60 years or older was similar to those with diabetes ( 31.7 versus $32.0 \%$ ), lower among those with hypertension $(42.2 \%$ versus $47.0 \%)$ and higher in patients with both hypertension and diabetes $(59.4 \%$ versus $54.6 \%) .{ }^{(16)}$ In these comparisons, it should be considered, again, that our study evaluated patients aged up to 79 years.

Our results showed higher participation of women in MHP, i.e., $70.0 \%$ of participants of the program were women. A similar result was observed in a study conducted in the city of Rio de Janeiro (RJ) in 2005 , in which women represented $71.7 \%$ of enrolled participants. $^{(17)}$ Regarding to SMGP, $20.0 \%$ of patients with diabetes and $18.8 \%$ of those with hypertension and diabetes were enrolled in the program, i.e., they were using insulin. These proportions are lower than those observed in study carried out in Brazil between 2006 and 2011 including adult patients with type 2 diabetes, in which $22 \%$ were using oral medications and insulin, and $13 \%$ insulin alone. ${ }^{(18)}$ However, our results presented values above of those observed in the study conducted in the city of Ribeirão Preto (SP) from 2006 to 2007 , in which $11.4 \%$ of patients with diabetes were using insulin associated with oral medicines and 3.4\% used insulin isolated. ${ }^{(19)}$

Regarding diseases diagnoses, our results $(68.0 \%$ with hypertension, $7.9 \%$ with diabetes and $24.1 \%$ with both diseases) were similar to a study conducted in 2011 with patients assisted by PHC of the city of Porto Alegre (RS), that reported proportions of $66,5 \%$ with hypertension, $6,5 \%$ with diabetes and $27,1 \%$ with both diseases. $^{(14)}$ In the study conducted in the city of Cambé (PR), $74.6 \%$ of patients had hypertension, $3.1 \%$ had diabetes and $22.3 \%$ both diseases, which are higher in relation to hypertension, lower in relation to diabetes and similar in relation to both diseases, in comparison with our results. ${ }^{(15)}$ Another study, including patients from three basic health units from the city of Pelotas (RS), observed lower proportions regarding hypertension 
$(63 \%)$ and diabetes $(2.5 \%)$, and higher proportion among patients with both diseases $(31.3 \%)$. $^{(16)}$

In our study almost one third of patients were classified with low CVR and half of them with high CVR. These results are different from those found in a study conducted in the city of Cambé (PR), in which patients with hypertension and/or diabetes were classified with low (40.8\%), moderate (40.2\%) and high $(19.0 \%)$ CVR. ${ }^{(15)}$ However, our results are similar to the study conducted with patients with hypertension with 20 or more years of age from a PHC unit in the city of Ribeirão Preto (SP), where $34.8 \%$ of patients had low CVR, $20.4 \%$ moderate CVR, and $45.0 \%$ high CVR. ${ }^{(20)}$ In this study, we must consider that, although $24.1 \%$ of patients with hypertension were also diagnosed with diabetes, patients with diabetes only were not evaluated.

Within the strategic action plan for coping with chronic non-transmissible diseases in Brazil, the PHC has the role, among other aspects, of providing assistance and integral care, and organizing reference and counter reference of these patients in health care network. ${ }^{(21)}$

Regarding the strategies used by $\mathrm{PHC}$ in the approach, assistance and patients care with chronic diseases several types were identified. A systematic review of published results between 2006 and 2014 evaluated these interventions, using as reference elements from care model for patients with chronic diseases. Most of these studies evaluated patientrelated outcome categories, using one or two elements of the model, most of the investigated diseases were hypertension and diabetes. ${ }^{(22)}$

In chronic diseases care model that is proposed by Brazilian Public Health System, the characterization of individuals, according to age, sex, hereditary factors and other risk factors, such as hypertension and diabetes, appears from the third level of risk stratum of health condition. ${ }^{(23)}$ In relation to hypertension, the use Framingham CVR score is recommended for risk stratification and follow-up of these patients. ${ }^{(24)}$ For patients with diabetes, there are recommendations to consider risk stratification according to metabolic and pressure control, hospitalizations for acute complications, presence of chronic complications, other comorbidities and social risk. ${ }^{(25)}$

Thus, patients' stratification based on risk can be considered part of health services organization strategy to chronic diseases approach, seeking to identify patients' different needs and to plan adequate activities based on stratum risk from each group and service resources. ${ }^{(23)}$

\section{CONCLUSION}

Prevalence, continuous care and possible complications associated with hypertension and diabetes represents a challenge for care of these diseases. The knowledge of characteristics of patients with hypertension and/or diabetes, especially the cardiovascular risk stratification, can help in organizing the approach, assistance and care for these patients.

\section{ACKNOWLEDGMENTS}

We thank all professionals from Primary Health Care units for the contribution in recording patients' data in spreadsheets, to the team from the Indicators and Information System Center that organized the database, and to Ana Carolina Cintra Nunes Mafra, $\mathrm{PhD}$, for the statistical analysis of data.

\section{AUTHORS' INFORMATION}

Sarno F: https://orcid.org/0000-0003-0687-940X

Bittencourt CA: https://orcid.org/0000-0002-4295-5337

Oliveira SA: https://orcid.org/0000-0003-4536-381X

\section{REFERENCES}

1. NCD Risk Factor Collaboration (NCD-RisC). Worldwide trends in blood pressure from 1975 to 2015: a pooled analysis of 1479 population-based measurement studies with $19 \cdot 1$ million participants. Lancet. 2017;389(10064):37-55.

2. Ogurtsova K, Rocha Fernandes JD, Huang Y, Linnenkamp U, Guariguata L, Cho $\mathrm{NH}$, et al. IDF Diabetes Atlas: Global estimates for the prevalence of diabetes for 2015 and 2040. Diabetes Res Clin Pract. 2017;128:40-50.

3. Brasil. Ministério da Saúde. Secretaria de Vigilância em Saúde. Departamento de Vigilância de Doenças e Agravos não Transmissíveis e Promoção da Saúde. Vigitel Brasil 2016: vigilância de fatores de risco e proteção para doenças crônicas por inquérito telefônico: estimativas sobre frequência e distribuição sociodemográfica de fatores de risco e proteção para doenças crônicas nas capitais dos 26 estados brasileiros e no Distrito Federal em 2016 [Internet]. Brasília (DF): Ministério da Saúde; 2017 [citado 2018 Abr 17]. Disponível em: http://bvsms.saude.gov.br/bvs/publicacoes/vigitel_brasil_2016_fatores risco.pdf

4. Colosia AD, Palencia R, Khan S. Prevalence of hypertension and obesity in patients with type 2 diabetes mellitus in observational studies: a systematic literature review. Diabetes Metab Syndr Obes. 2013;6:327-38. Review.

5. Picon RV, Dias-da-Costa JS, Fuchs FD, Olinto MT, Choudhry NK, Fuchs SC Hypertension Management in Brazil: Usual Practice in Primary Care - A MetaAnalysis. Int J Hypertens. 2017;2017:1274168. Review.

6. Brasil. Ministério da Saúde. Secretaria de Atenção à Saúde. Departamento de Atenção Básica. Política Nacional de Atenção Básica [Internet]. Brasília (DF): Ministério da Saúde; 2012. [Série E. Legislação em Saúde] [citado 2018 Abr 17]. Disponível em: http://189.28.128.100/dab/docs/publicacoes/geral/ pnab.pdf

7. Brasil. Ministério da Saúde. Gabinete do Ministro. Portaria $n^{0} 483$, de $1^{0}$ de abril de 2014. Redefine a Rede de Atenção à Saúde das Pessoas com Doenças Crônicas no âmbito do Sistema Único de Saúde (SUS) e estabelece diretrizes para a organização das suas linhas de cuidado [Internet]. Diário Oficial da União n 34, Seção 1. Brasília (DF): Ministério da Saúde; 2014 [citado 2017 Abr 22]. Disponível em: http://bvsms.saude.gov.br/bvs/saudelegis/gm/2014/ prt0483 $01 \quad 04$ 2014.html 
8. Malta DC, Stopa SR, Andrade SS, Szwarcwald CL, Silva Junior JB, Reis AA. Health care in adults with self-reported hypertension in Brazil according to the National Health Survey, 2013. Rev Bras Epidemiol. 2015;18(Suppl 2): 109-22.

9. Malta DC, Iser BP, Chueiri PS, Stopa SR, Szwarcwald CL, Schmidt MI, et al. Health care among adults with self-reported diabetes mellitus in Brazil, National Health Survey, 2013. Rev Bras Epidemiol. 2015;18(Suppl 2):17-32.

10. Guibu IA, Moraes JC, Guerra Junior AA, Costa EA, Acurcio FA, Costa KS, et al. Main characteristics of patients of primary health care services in Brazil. Rev Saude Publica. 2017:51(Suppl 2):17s.

11. Brasil. Ministério da Saúde. Secretaria de Atenção à Saúde. Departamento de Atenção Básica. Estratégias para o cuidado da pessoa com doença crônica. Cadernos de Atenção Básica, n. 35 [Internet]. Brasília (DF): Ministério da Saúde; 2014 [citado 2018 Abr 17]. Disponível em: http://conitec.gov.br/ images/pdf/Caderno_AtencaoBasica35.pdf

12. Prefeitura de São Paulo. Secretaria Municipal de Saúde. Programas. Remédio em Casa [Internet]. São Paulo; 2017 [citado 2017 Abr 22]. Disponível em: http://www.prefeitura.sp.gov.br/cidade/secretarias/saude/programas/index. php? $\mathrm{p}=5875$

13. Prefeitura de São Paulo. Secretaria Municipal de Saúde. Programas. AMG - Programa de Automonitoramento Glicêmico [Internet]. São Paulo; 217 [citado em 2017 Abr 22]. Disponível em: http://www.prefeitura.sp.gov.br/ cidade/secretarias/saude/programas/index.php? $\mathrm{p}=6070$

14. Baldisserotto J, Kopittke L, Nedel FB, Takeda SP, Mendonça CS, Sirena SA, et al. Socio-demographic characteristics and prevalence of risk factors in a hypertensive and diabetics population: a cross-sectional study in primary health care in Brazil. BMC Public Health. 2016;16:573.

15. Radigonda B, Souza RK, Cordoni Junior L, Silva AM. Assessment of the follow-up of adult patients with arterial hypertension and/or diabetes mellitus by the Family Health Strategy and identification of associated factors in the city of Cambé, Brazil, 2012. Epidemiol Serv Saude. 2016;25(1):115-26.

16. Lima LM, Schwartz E, Muniz RM, Zillmer JG, Ludtke I. Perfil dos usuários do hiperdia de Três unidades básicas de saúde do sul do Brasil. Rev Gaucha Enferm. 2011;32(2):323-9.
17. Simões JM, Monteiro MG. Estratégias de apoio às políticas públicas de saúdeo remédio na experiência do projeto da casa. Mundo Saúde. 2006;30(2):289-99.

18. Viana LV, Leitao CB, Kramer CK, Zucatti AT, Jezini DL, Felicio J, et al. Poor glycemic control in Brazilian patients with type 2 diabetes attending the public healthcare system: a cross-sectional study. BMJ Open. 2013;3:e003336.

19. Guidoni CM, Borges AP, Freitas Od, Pereira LR. Prescription patterns for diabetes mellitus and therapeutic implications: a population-based analysis. Arq Bras Endocrinol Metabol. 2012;56(2):120-7.

20. Cesarino EJ, Vituzzo AL, Sampaio JM, Ferreira DA, Pires HA, Souza L. Assessment of cardiovascular risk of patients with arterial hypertension of a public health unit. einstein (São Paulo). 2012;10(1):33-8.

21. Brasil. Ministério da Saúde. Secretaria de Vigilância em Saúde. Departamento de Análise de Situação de Saúde. Plano de ações estratégicas para o enfrentamento das doenças crônicas não transmissíveis (DCNT) no Brasil 2011-2022 [Internet]. Brasília (DF): Ministério da Saúde; 2011 [Série B. Textos Básicos de Saúde]. [citado 2018 Abr 17]. Disponível em: http:// bvsms.saude.gov.br/bvs/publicacoes/plano_acoes_enfrent_dcnt_2011.pdf

22. Reynolds R, Dennis S, Hasan I, Slewa J, Chen W, Tian D, et al. A systematic review of chronic disease management interventions in primary care. BMC Fam Pract. 2018;19(1):11.

23. Organização Pan-Americana da Saúde. Organização Mundial da Saúde. Conselho Nacional de Secretários de Saúde. 0 cuidado das condições crônicas na atenção primária à saúde: 0 imperativo da consolidação da estratégia da saúde da família [Internet]. Brasília (DF): Organização Pan-Americana da Saúde; 2012 [citado 2018 Abr 17]. Disponível em: http://bvsms.saude.gov. br/bvs/publicacoes/cuidado_condicoes_atencao_primaria_saude.pdf

24. Brasil. Ministério da Saúde. Secretaria de Atenção à Saúde. Departamento de Atenção Básica. Estratégias para o cuidado da pessoa com doença crônica: hipertensão arterial sistêmica. Cadernos de Atenção Básica, n. 37 [Internet]. Brasília (DF): Ministério da Saúde; 2013 [citado 2018 Abr 17]. Disponível em: http://189.28.128.100/dab/docs/portaldab/publicacoes/caderno_37.pdf

25. Brasil. Ministério da Saúde. Secretaria de Atenção à Saúde. Departamento de Atenção Básica. Estratégias para o cuidado da pessoa com doença crônica: diabetes mellitus. Cadernos de Atenção Básica, n. 36 [Internet]. Brasília (DF): Ministério da Saúde; 2013 [citado 2018 Abr 17]. Disponível em: http://189.28.128.100/dab/docs/portaldab/publicacoes/caderno_36.pdf 